Published on Reviews in History (https://reviews.history.ac.uk)

\title{
The French Army and the First World War
}

Review Number: 1746

Publish date: Thursday, 26 March, 2015

Author: Elizabeth Greenhalgh

ISBN: 9781107012356

Date of Publication: 2014

Price: $£ 55.00$

Pages: 400pp.

Publisher: Cambridge University Press

Publisher url: http://www.cambridge.org/gb/academic/subjects/history/military-history/french-army-and-first-world war?format $=\mathrm{HB}$

Place of Publication: Cambridge

Reviewer: Mario Draper

As Elizabeth Greenhalgh alludes to in the introduction of her well-researched and constructed monograph, The French Army and the First World War, common perceptions of France's military experience between 1914 and 1918 have tended to be reduced to mere flashpoints of interest. Obvious examples would naturally include the Miracle of the Marne, Verdun and the 1917 mutinies. Indeed, for British readers these are likely to have weathered the test of time respectively through association with the opening engagements of the BEF; the sheer weight of tragedy (accessible both visually and emotionally through visits to its renowned ossuary and surrounding sites of remembrance); as well as being indelibly etched into popular culture by Stanley Kubrick's interpretation of events in Paths of Glory (1957). Yet acceptance of such a limited view means missing the essential impact, over a sustained and continuous period of time, of the Allied Forces' largest and most influential contributor. It is this scale, a theme returned to in many different guises throughout the ostensibly chronological account, which Greenhalgh manages to convey with immense clarity. Not only did it affect the French Army's operational undertakings across numerous theatres; or its materiel, and by extension economic, output to support these and her allies' campaigns, but it also proved to be a dislocating and subsequently a unifying influence on the relationship between army and society.

As an overview of the French military experience, there is naturally a focus on the men who commanded the army. Much like John Gooch's characterisation of Luigi Cadorna in his book on the Italian Army of the same series (also reviewed by this author), Greenhalgh draws a certain degree of attention to, and insight from, the experience of the well-known figures of Joseph Joffre, Philippe Pétain and Ferdinand Foch.(1) Whilst there is no shying away from using her own recent work on Foch where appropriate, it is commendable how extensive Greenhalgh's research on other personalities, and the army as a whole, has been for this monograph.(2) Indeed, the synthesis of a large volume of secondary literature, memoirs, and archival sources provides a varied wealth of riches upon which to construct the narrative. In an attempt to avoid an overwhelming deluge of materiel from suffocating the analysis, particularly with regard to more localised studies of operations, Greenhalgh uses the records of a single Division (the 13 DI) to provide 'a series of narrative hooks to make more comprehensible the huge numbers involved in this, the first modern industrial war' (p. 2). In so much as it could potentially be viewed as a limiting factor due to the singularity of experience of one unit, the selection of $13 \mathrm{DI}$ is justified by the commonalities it shared with many other 
units. Indeed, used (as it is) to add another layer of information from a source lower down the chain of command, it can only be viewed as a resounding success.

Greenhalgh opens her account by exploring the complicated link between the army and the nation following defeat in the Franco-Prussian War. It is noted that two of the Third Republic's great achievements, a colonial empire and compulsory education (both somewhat influenced by the work of Jules Ferry) proved to be a source of regeneration of French national pride. The Prussians had supposedly won the war in 1870 in the classroom and so it was to be in France. Not only would it provide a more literate and intelligent class of recruit but also had the potential, through its uniformity, to harness a sense of nationalism from across its disparate regions (pp. 8-9). Whilst Greenhalgh readily accepts that in conjunction with the evolving conscription laws, a powerful sense of military values and civic duties 'had inculcated a generation of compulsorily educated primary school children', she gives less credit to the army in this development than would some others (p. 14). Douglas Porch, for instance, argued that it was national service, regional recruitment and military reform, first and foremost that had fostered such values, with the republican social developments merely complementing a mechanism that was already in place.(3) In essence they are two sides of the same coin, with the important factor for France's wartime experience being that it could call on a citizen army with the ability to both express itself in writing and draw on an abstract concept in a bid to endure the intensity of industrialised war. In essence, they both proved to be a source of strength, directly linking the army with the society from which it was drawn.

Joffre's assessment of the French Army's ability to emerge victorious was judged to be below 70 per cent in 1911 during the provocation of the Agadir crisis, and therefore not enough in the republic's favour to go to war (p. 36). Three years later a war of unprecedented scale was forced upon him and the nation. What he believed his chances of victory were at this juncture remain a mystery, but certainly he retained a calmness in his thought and confidence in his action that belied the situation of an army struggling to cope with its baptism of fire. The sheer number of executions between September and December 1914 proved to be three times as high as in 1917, demonstrating just how dislocating the volume of casualties and the disillusionment of a war was (p. 62). Even the Government physically distanced itself to Bordeaux in early September when a German breakthrough towards Paris appeared likely. This allowed Joffre greater leave of action, which, in conjunction with the energy shown by Foch, somewhat altered the fortunes of the retreating Allied forces. Greenhalgh's emphasis on the influence of both men is a notable feature of the monograph.

Their respective roles in 1914 do not go unnoticed and neither do the consequences. In a campaign, in which First Ypres is recast as coalition battle and not just a British one, the responsibility undertaken by the French is displayed as an early point of recognition of their primacy within the alliance. Indeed, Greenhalgh goes as far as to suggest that it earmarked Foch as the ideal candidate for the role of Supreme Commander in March 1918 (p. 52). Whereas both figures were undoubtedly highly influential amongst their allies during the 1914 crisis, Greenhalgh's unreferenced claim that it was Joffre who convinced the Belgians to remain on the Yser rather than retreat into France appears to be somewhat wide of the mark (p. 51). The Belgians were in disarray and involved in a fighting retreat south from Antwerp at the end of October, but stood firm on account of the tenacity of King Albert who wished to keep a physical presence on home soil for symbolic purposes. $(4)$

With the return of the Government to Paris came reduced independence for Joffre in the 1915 campaigns. Civil-military relations caused tensions within all belligerents and were often brought to a head over how, when and where a decisive blow could be delivered. France was no exception. Not only did politicians force the army to divert manpower and resources to support the establishment of what were militarily perceived as unnecessary fronts in the Dardanelles and Salonika, but also their physical proximity ensured fiercer scrutiny of how the war was being fought. Georges Clemenceau's revelation of the state of the army's medical services in L'Homme Libre is a case in point (pp. 61-8). Whereas operations in the East appeared to relieve pressure on their Russian allies, whilst simultaneously satisfying French colonial ambitions to extend their sphere of influence into the Balkans (p. 100), the Western Front was criticised for expending too much French blood for comparatively little gain. Despite the shell crisis that had caused the major armies to take stock of proceedings, Greenhalgh's main thrust in the operational sphere of 1915 is that it was far from a lull 
between the dynamism of the Marne and the slaughter at Verdun. Indeed, the French carried out a series of operations under pressure from allies, who in the case of the British under Sir John French, proved particularly difficult to deal with.

Given the scrutiny over the conduct of operations, Greenhalgh seizes the opportunity to take the first of many steps into understanding the tactical evolution of the French Army during the Great War. As with all belligerents, this process flowed both up and down the chain of command and was far from being a uniform learning process, with codified doctrine often proving misguided, soon out-dated or simply not implemented. For example, the 1915 campaign had demonstrated that initial success could be achieved through wellplanned attacks supported by a high concentration of artillery. However, Grand Quartier Général (GQG), remained intent on circulating directives on speed and continuity in order to return to a war of movement and achieve a decisive victory (pp. 88-9). It soon became clear that if doctrine was to be effective it would have to be sent up the hierarchical chain for lessons to be extracted before redistribution (p. 120). This, as Greenhalgh aptly demonstrates, was to be a common occurrence throughout the war, with Foch's dissemination of doctrine for the Somme offensive based largely on his observations of events at Verdun ( $p$. 151). Similarly, Pétain's understanding of the value of technology as well as his willingness to incorporate lessons taken from the German Army, such as elastic defence, demonstrated the value of the French system. However, even this latter point was resisted by some, despite recognition of its success (p. 249). Pétain's success in advocating the limited offensive was not a decisive method but proved particularly agreeable in the wake of the Nivelle offensives that had seen the poor implementation of local methods of success on a grander scale. Ultimately, Greenhalgh concludes that the evolutions in the art of warfare undertaken by the French Army of 1914 meant that it had 'changed more profoundly by November 1918 than the BEF or AEF did from a later start' (p. 394).

As with the previous two years of the war, 1916 proved to be one of coalition. Verdun naturally stands out as the epicentre of French operational affairs due its scale and solitary nature. Whilst Greenhalgh naturally devotes to it the attention that it rightfully deserves, particularly the manner in which it was fought, this chapter seeks to reassert the extent of French participation alongside the British on the Somme. Indeed, preparations for a coordinated offensive had not been hampered by the failures of 1915; Joffre still held his position as de facto head of the Entente Armies on the Western Front and had seemingly retained the confidence of British Prime Minister, H. H. Asquith who referred to him as 'Super-Frog' (p. 127). With support from Paris at a premium, this proved to be Joffre's last saving grace, which he attempted to exploit to retain his position. The first Chantilly conference reaffirmed the Allied presence in Salonika and pushed for decisive action through simultaneous offensives on all fronts. The Somme was to be the site of the Franco-British effort and even the German attack at Verdun could do little to prevent it. Whereas 1 July resonates with uncompromising failure for the majority of the British Army, the opening phases of the battle were a great success for the French, whose desire to exploit their gains were curtailed by the fact that their ally was no longer in a position to offer mutual support (pp. 153-4). The weight of expectation placed on Joffre to achieve success that would encourage Romania to declare for the Allies began to show itself as the battle ground to a halt. His exasperation grew at having to deal with an obstinate Haig on the one hand and subsequently his superiors on the other, whose concerns about the cumulative effect of casualties led to increased interference in military affairs. Ultimately, the war appears to have outrun Joffre and not even his standing among his allies could prevent his replacement by Robert Nivelle whose local success at Verdun had impressed more than Pétain's caution or the apparent failure of the Foch's operation on the Somme.

Whereas Greenhalgh consistently attempts to promote the abilities, influence and roles of Joffre, Foch and Pétain, there is seemingly little that can be done to rebuild the reputation of Nivelle, whose offensives in 1917 all but crippled the army to the point of morale and physical collapse. Indeed, in her appraisal, his performance and ideas are described as being from 'cloud-cuckoo-land', which hardly seeks to readdress the current historiographical trend (p. 179). Simply put, he was over-promoted and unable to generate the respect and support required from the likes of Haig, Lloyd-George and his subordinates, which undermined his ability to command effectively (p. 198). The degree of failure was as much measured in these terms as it was in casualties and the rapidity with which the politicians lost faith. 'Nivelle had lasted the shortest time of 
any of the CinCs of the belligerents, less than five months. There has been no appeal against history's verdict that Nivelle's command was a disaster' (p. 197). Perhaps Nivelle proved to be the foil against which his predecessor and successors' capabilities were able to flourish.

Pétain's 'healing' of the army was less about personality per se but more a result of his 'sense of organisation' as Greenhalgh puts it (p. 220). These skills, which had been demonstrated during the defence of Verdun, proved invaluable in regenerating an ailing and fatigued army. The breakdown in discipline was not unexpected and coincided with similar problems in other armies. It is this very point that leads Greenhalgh to pose the question of what exactly constitutes mutiny, as in her eyes, what transpired in the French Army in 1917 was nothing out of the ordinary. In her words: 'The various incidents were so disparate in type, extent and duration that it has proved hard to define precisely what constituted the 1917 "mutiny". Do drunken groups of soldiers proclaiming anti-war sentiments? Does the reading of pacifist literature handed out en route home? Does one or two men slipping away but returning to their units a few days later? If so, is there a figure that has to be attained in order to alter the nature of the case from an individual's misdemeanour to a full-scale mutiny? (p. 220) These are all valid questions asked by Greenhalgh; though somewhat superfluous when it is considered that an alternative definition is not forthcoming and the terms 'mutiny' and 'mutineers' are readily used in the ensuing discussion of events. Perhaps something akin to David Englander's use of the term 'strike' might have provided a useful working definition in order to distance the events from the violent term mutiny, in favour of more peaceful demonstrations.(5) Nevertheless, the attempt to calculate the numbers and composition of those involved is compelling. Somewhere between 25,000 and 88,000 men (depending on the source) or more poignantly a good half of French Divisions (p. 201). Although the traditional explanation for this outbreak of indiscipline (lack of sufficient leave) cannot be, and is not, dismissed, Greenhalgh advances the notion that much of it was politically inspired. 'The attempt to storm trains so as to reach the capital and their political representatives, and the letters written to deputies, show that the men's aims were an end to the war'. Not only that, it is convincingly portrayed as being a direct reaction to events in Russia (p. 208). In consequence, there was little 'healing' to be done. Rather, the product of the Third Republic's compulsory education system merely wished to express themselves through the limited citizenly mechanisms available to them during times of war.

In a similar vein to her reappraisal of 1915 and the Somme offensive in 1916, Greenhalgh puts forward a compelling case to redistribute some of the glory of victory away from the British and Americans, and back into French hands. Their contribution, not only in the person of Foch as Supreme Commander, but in continuing to supply new materiel to allies and in the operational sphere was significant, albeit curtailed by a premature armistice. Indeed, the mere fact that the new French Premier, Georges Clemenceau, felt the need to publicly defend his Generals, Pétain and Foch, over the casualties sustained in repelling the German Spring Offensives is demonstration enough of the extent of French military involvement (p. 304). The desire among politicians to see heads roll was probably symptomatic of war-weariness as neither Pétain's or Foch's performances were poor. Quite the contrary, Greenhalgh lauds Foch, in particular, for his energy in shoring up the gap between the British and French armies following the confusion wrought by Operation Michael. It proves to be the point where the admiration for Foch begins to outshine the respect for Pétain. Greenhalgh firmly backs Foch's tireless aggression in the final months of the war, exposing Pétain's over-cautiousness as well as obstinacy in the face of subordination to the only man who was capable of ending the war when it did: 'Had Pétain been in supreme command, no armistice could have been signed in 1918, let along at Rethnodes on 11 November' (p. 337).

With the war coming to an end, attentions turned to the diplomatic settlement to come. Franco-British tensions were unavoidable, especially concerning Palestine where Greenhalgh once again endeavours to highlight the French contribution alongside Laurence of Arabia (pp. 349-50). In the West, British and American success irked French generals who were fearful of losing out on the opportunity for glory in delivering the final blow. Plans for an offensive in Lorraine were completed but the operation was stillborn upon the signing of the armistice before its launch. Much was made of this by Pétain who claimed that France had been robbed of a military victory, which directly lead to the Second World War. However, as 
Greenhalgh perceptively notes, 'This judgement assumes that a victory in Lorraine was on offer - Pétain was unlikely to be as energetic pushing the enterprise forward as Foch, say, would be - and it is a judgement made with hindsight, as the Hitlerian threat became ever more manifest' (p. 361). More to the point, the opportunity to avoid more bloodshed was presented to Foch who also saw it as a clear opportunity to enforce his stiff peace terms before too many external parties could interfere. Barring a few tensions during demobilisation, where the desire to return home triumphed over the military necessity to retain an adequate army in the event of a resumption of hostilities, the war ended without much incident for the ordinary poilus who now had to embark upon a different journey of re-assimilation into a much changed civilian society.

Again, in some concluding remarks Greenhalgh reemphasises the magnitude of France's participation in the Great War. Numerically it mobilised 8,410,000 men, and a further 475,000 colonial natives from its possessions around the world. The estimated loss, albeit not an exact figure, totalled an astonishing 1,383,000 dead and missing (p. 377). Born out of the schools of the Third Republic it truly was a citizen army, and one which proved an adaptability and flexibility that Greenhalgh believes saw it eventually win out (p. 378). Much credit must also go to its senior officers who, by and large, were amenable to such ideas under truly alien conditions of modern industrialised war. Not that anyone ever seriously doubted the contribution of French participation, but perhaps it was never properly understood. What Elizabeth Greenhalgh has done here is mirror one of the key themes underscoring French military success during the Great War: she has extracted the valuable lessons to be learnt, codified them, and now presented them for redistribution. Given the quality of the extensive research, clarity with which it is delivered and the insightfulness on offer, The French Army and the First World War - retailing at $£ 19.99$ (softcover) and $£ 55.00$ (hardcover) must be viewed as a mainstay in the historiography of the Great War.

\section{Notes}

1. J. Gooch, The Italian Army and the First World War (Cambridge, 2014). Back to (1)

2. E. Greenhalgh, Foch in Command: The Forging of a First World War General (Cambridge, 2011). Back to (2)

3. Douglas Porch, The March to the Marne: The French Army 1871-1914 (Cambridge, 1981), p. 32. Back to (3)

4. Hew Strachan, The First World War: Volume I: To Arms (Oxford, 2001), pp. 273-6.Back to (4)

5. David Englander, 'The French soldier 1914-1918', French History, 1 (1987), 53. It is also used with regard to the Belgian troubles in March 1918 in David Englander, 'Mutinies and Morale', in The Oxford Illustrated History of the First World War, ed. Hew Strachan (Oxford, 1998), p. 198. Back to $\underline{(5)}$

The author is happy to accept this review and thanks the reviewer for his kind comments.

Source URL:https://reviews.history.ac.uk/review/1746

\section{Links}

[1] https://reviews.history.ac.uk/item/112601 